\title{
The Effect of Corporate Social Responsibility on Customer Trust, Customer Satisfaction and Customer Loyalty: Uber Service in Egypt
}

\author{
Dr. Hany Nasr Eldin \\ Assistant Professor \\ Faculty of Commerce and Business Administration \\ Future University \\ Arab Republic of Egypt \\ hany.abdulmoniem@fue.edu.eg
}

\author{
Dr. Asmaa Alhassan \\ Assistant Professor \\ Faculty of Management and Information Systems \\ Université Française \\ Arab Republic of Egypt \\ asmaa.sharif@ufe.edu.eg
}

\begin{abstract}
This study aims to provide in depth understanding of the direct and indirect effect of Corporate Social Responsibility (CSR) on customer satisfaction, customer trust and customer loyalty. Collected from 329 Egyptian people who used UBER service, data were analyzed using Smart PLS 3. Research results indicate that CSR has a direct effect on customer satisfaction, but no direct relationship has been found between CSR and customer trust and loyalty. Results also indicate that customer satisfaction influences both customer trust and customer loyalty and thus plays a mediating role in the relationship between CSR and customer trust and loyalty.
\end{abstract}

Keywords: Corporate Social Responsibility; Customer trust; Customer satisfaction; Customer loyalty; Uber service; Egypt.

\section{Introduction}

The concept of CSR in the management of companies has developed considerably in recent years. Many companies are now aware of their duties regarding the society and the environment, and keen to adopt a socially responsible behavior. Thus, they tend, now more than ever, to invest financially to enhance their goodwill. They are sometimes pressured by shareholders and sometimes by the media (for instance, the media coverage of the working conditions in France). In fact, CSR can be a mean to satisfy both shareholders and stakeholders in general (e.g., suppliers, customers, the government, the community) (Maignan et al., 2005; Islam et al., 2018). CSR has also become a competitive strategic orientation used by companies to increase their profits via customer satisfaction, customer loyalty, and positive attitudes towards the company's brands (Calabrese et al., 2016).

Thus, some previous studies have discussed the impact of adopting a socially responsible behavior on the financial performance of the company (Aupperle \& Hatfield, 1985; Luo \& Bhattacharya, 2006). Other researchers concluded that, from a strategic perspective, CSR can create a sustainable competitive advantage (Barney, 1991; McWilliams \& Siegel, 2011). In the field of marketing research, many previous studies have discussed the impact of CSR on customer satisfaction (Brown \& Dacin, 1997; Berens et al., 2005), customer trust (Kennedy et al. 2001; Ball et al., 2004; Swaen \& Chumpitaz, 2008), and customer loyalty (García de los Salmones et al., 2005; He and Li, 2011; Marin et al., 2009; Perez et al., 2013). But few studies investigated the role of customer satisfaction and customer trust in the identification of the relationship between CSR and customer loyalty (Sindhu \& Arif, 2017).

\footnotetext{
* This article was submitted in February 2021, and accepted for publishing in March 2021.

(c) Arab Administrative Development Organization- League of Arab States, 2023, pp 227-246، DOI: 10.21608/aja.2021.63579.1046
} 
Whereas a number of studies demonstrated a positive direct relationship with no mediating variables between CSR and customer loyalty (García de los Salmones et al., 2005; He and Li, 2011; Marin et al., 2009; Perez et al., 2013), a number of recent researches have proven the opposite, confirming surprisingly the mediating role of corporate reputation, customer trust, and customer satisfaction between CSR and customer loyalty (Islam et al., 2020). As previous researchers have identified customer satisfaction and customer trust as key determinants of customer loyalty (Heskett et al., 1997; Bansal et al., 2004; Pivato et al., 2008; Hamadi, 2010; Gul, 2014), our research focuses not only on investigating the direct effect of CSR on customer loyalty, but also the mediating role of customer satisfaction and customer trust in this relationship.

Therefore, in this research, we will address the following questions:

- Does CSR affect customer satisfaction?

- Does CSR affect customer trust?

- Does CSR influence customer loyalty directly?

- What is the effect of customer trust on customer loyalty?

- What is the effect of customer satisfaction on customer loyalty?

- What is the role of customer trust and customer satisfaction in the relationship between CSR and customer loyalty? Can they be considered as mediators?

\section{Literature Review:}

\section{CSR}

Most of the researches done in the sustainability field have discussed the concern of the CSR regarding the natural environment, how to save the natural resources, what are the main causes of the global warming and the consequences of it and the climate changes effect (Hagoveldand \& Svensson, 2011). Therefore, CSR can be studied from three different main perspectives:

- The CSR pyramidal theory focusing on the economic, legal, ethical, philanthropic dimensions, Carroll (1979). From this perspective, CSR is defined as all the 'economic, legal, ethical and discretionary expectations that society has of organizations at a given point in time' (Carroll, 1979).

- The sustainable development theory focusing on the economic, environmental, and social perspective. From this perspective, CSR is defined as a "context-specific, strategic, proactive, and synergistic philosophy of doing business according to which corporations need to pay attention to economic, environmental and social issues in a balanced way" (Panwar et al., 2006). White (2009) defined sustainability as per the Procter \& Gamble (P\&G) definition. In fact, P\&G a global consumer company, with more than 300 brands sold in 180 countries, and 138,000 employees, is working hard on sustainability in order to bring it into its business. For P\&G, sustainability goes beyond social investment programs it includes issues such as product design, manufacturing operations, employee engagement and stakeholder partnerships. The definition used by White and adopted by $P \& G$ for sustainability is the broader term used by corporations and researchers "ensuring better quality of life, now and for generations to come" focusing on the three pillars of environmental protection, social responsibility, and economic development.

- The stakeholder management theory focusing on shareholders, customers, employees, society, and other dimensions (Pérez \& Rodriguez del Bosque, 2013). Thus, CSR refers to it as all 'company activities demonstrating the inclusion of social and environmental concerns in business operations, and in interactions with stakeholders, also according to the ambition levels of CSR (Van Marrewijk, 2003; Pérez \& Rodriguez del Bosque, 2013). 
This study focuses more on the sustainable development theory from the environmental and social perspective. Brown and Dacin (1997) worked on the CSR associations which reflect the organization's perceived societal obligations. Varadajarn and Menon (1998) studied increasing the company's visibility through cause related marketing. Corporate involvement in social well-being started first as a response to social problems, then it evolved into a different phase where social responsibility is perceived as an investment by the company (Stroup \& Neubert, 1987).

\section{Customer Satisfaction}

Satisfaction is vital to marketing because it can help predict purchase behavior (repurchase, purchase intentions, brand choice and switching behavior) (Oliver, 1993; McQuitty et al., 2000; Al-Msallam, 2015). Studies have also shown that the durable success of a firm is strictly related to its facility to adapt to customers' changing needs and preferences (Takala et al., 2006). Various definitions of satisfaction have been presented in marketing literature. Oliver (1981) defined satisfaction as either an emotional post consumption response for comparing expected and actual performance, or an outcome without comparing expectations. Woodruff et al. (1983) stated that customer satisfaction is an instant emotional response which reflects actual performance. Fornell (1992) defined satisfaction as "overall evaluation after purchase". Whereas Kotler (2000) defined satisfaction as a feeling resulting from comparing expectations and performance. Satisfaction can also be defined as an overall evaluation of post-consumption experience of products or services in the minds of customers (Luo \& Bhattacharya, 2006).

A distinction may also be done between transaction-specific and cumulative consumer satisfaction (Johnson et al., 1995; Andreassen, 2000; Al-Msallam, 2015). Transaction-specific consumer satisfaction is a post-consumption evaluative judgment of a specific purchase occasion (Oliver, 1981, 1993). In contrast, cumulative consumer satisfaction represents an overall evaluation based on the entire purchase and consumption experience with a product over time (Johnson \& Fornell, 1991; Fornell, 1992; Anderson et al., 1994, Al-Msallam, 2015).

Consumer satisfaction can be viewed in terms of the "disconfirmation of expectations paradigm" (Cadotte et al., 1987). This paradigm states that consumer brand evaluation involves comparing actual performance with certain standards. Three cases may take place as a result of this comparison:

1- Confirmation: when performance matches standards, leading to neutral feelings.

2- Positive disconfirmation: when performance is considered better than standard, resulting in satisfaction.

3- Negative disconfirmation: when performance is considered worse than standard, resulting in dissatisfaction

Consequently, increasing customer satisfaction would help businesses save costs, create profits, and establish reputations (Reichheld, 1996; Wu \& Wang, 2014). It can make demand more inelastic (Anderson, 1996; Simon et al., 2009), and reduce the costs for attracting new customers and dealing with poor quality, defects, and complaints (Anderson et al., 1997, Simon et al., 2009).

According to Roy (2013), satisfied customers will have intentions to advocate the service provider among their peers. Fullerton (2011) argues that if consumers feel contented in their relationship with a company or brand, they will act as advocates for this company or brand to give favorable recommendations (Price \& Arnould, 1999), and they will wish the success of the company (Brown et al., 2005).

\section{Customer Trust}

Trust is one of the most important keys to build a sustainable relationship not only between the company and its customers (Morgan \& Hunt, 1994; Fullerton, 2011, So et al., 2013), but also in all social relation- 
ships, which would fail or function irregularly without it (Patrick, 2002). Morgan and Hunt (1994) defined trust as confidence that one partner has on another partner because of honesty and reliability of the last. According to Crosby et al. (1990) customer trust could be defined as "the product and the service provider can be trusted in a way that long term interest of the customers will be served". In service context, Ganesan (1994) defined trust as belief that the service provider will deliver as promised and belief that the service provider is acting in the best interests of the customers and will not take advantage of the relationship. Based on this last definition, Doney and Cannon (1997) classified trust into two components: credibility (or performance) and benevolence. Credibility refers to customer's perception that the words and promises of a firm can be trusted (Doney \& Cannon, 1997; Fullerton, 2011). Benevolence refers to customers believes that firms motives and intentions are beneficial to customers (Cater \& Zabkar, 2009; Doney \& Cannon, 1997).

\section{Customer Loyalty}

There is no universally accepted definition of customer loyalty (Dick \& Basu, 1994; Oliver, 1999; Zhang et al., 2010). Oliver (1997, p. 392) defined it as "a deeply held commitment to rebuy or re-patronize a preferred product or service consistently in the future, thereby causing repetitive same-brand or same brand-set purchasing, despite situational influences and marketing efforts having the potential to cause switching behavior". Research often defines loyalty from two different perspectives: an attitudinal perspective or a behavioral perspective (Chaudhuri \& Holbrook, 2001; Han et al., 2011).

The attitudinal perspective maintains that true loyalty exists when there exist favorable beliefs toward the brand (Agustin \& Singh, 2005; Carrillat et al., 2009; Jacoby \& Kyner, 1973; Johnson et al., 2006). Customer loyalty operationalized as an attitude may be measured by brand preference, commitment or the intention-to-buy (Boulding et al., 1993, Narayandas, 1996, Cronin \& Taylor, 1992; Anderson \& Sullivan, 1993). Therefore, companies must know what consumers think of the brand. In fact, brand attitude could be an indication of consumers' likes or dislikes which could be used to predict consumers' buying willingness and brand loyalty (Burton et al., 1998).

The behavioral perspective views loyalty as expressed behavior, and usually defines loyalty as a customer's propensity to buy a brand with reference to the pattern of past purchases (Russell \& Kamakura, 1994; Sivakumar, 1994; Tellis, 1988). Customer loyalty operationalized as a behavior may be measured by hard-core loyalty or repeat purchase probability (Jeuland, 1979; Carpenter \& Lehmann, 1985; Colombo \& Morrison, 1989; Dekimpe et al., 1997; Lee et.al, 2001).

Ehigie (2006) defined loyalty as a feeling of commitment on the part of the customer to a product, brand, marketer, or services: staying with same provider. Therefore, customer desires to continue the relationship, even if competitors have lower prices (Ball et al., 2006). Further, loyalty includes a customer's intention not only to return to a service provider, but also to recommend the provider to others (Bendall-Lyon \& Powers, 2003; Ball et al., 2006). Thus, customer loyalty is considered as an important factor which leads to gain competitive advantage over other firms under a highly competitive and dynamic environment (Leninkumar, 2017). Harris and Goode (2004) agree also that loyalty in a competitive environment is of great importance because a loyal customer will tend to buy, pay, and recommend more. Therefore, companies do their best in order to satisfy their customers and to develop long-term relationship with them (Han \& Back, 2008; Martínez \& Rodriguez Del Bosque, 2013).

\section{CSR and Customer Satisfaction}

Different researches explained the link between CSR and customer satisfaction. According to Brown and Dacin (1997, p.81), "the personal values held by individual consumers may influence their evaluations 
of and behaviors toward companies and products. And thus, a consumer's behavior may be dependent on the extent to which a company's values and beliefs are in agreement with his or her value system". In fact, company's customers, as potential stakeholders, care about not only the economic performance of organizations but also about the overall standing (including social) performance of the company (Maignan et al., 2005). Daub and Ergenzinger (2005) proposed the term "generalized customer" to identify people who are not only simple customers but also members of different stakeholder groups that companies need to consider. These generalized customers are more satisfied by products and services offered by more socially responsible firms. Sen and Bhattacharya (2001) maintained that a strong record of CSR creates a favorable context that positively boosts consumers' evaluations of the firm and attitude toward it. According to Luo and Bhattacharya (2006) have also researched the link CSR and Customer Satisfaction. Customers are likely to be more satisfied if services or products providers develop CSR initiatives and present a socially responsible behavior toward society ( $\mathrm{He} \& \mathrm{Li}, 2011)$. Thus, this research proposes the following hypothesis:

\section{H1: Firms that are viewed more favorably with respect to CSR enjoy greater customer satisfaction}

\section{CSR and Customer Trust}

Many previous studies showed a significant effect of CSR on trust (Kennedy et al., 2001; Ball et al., 2004; Swaen \& Chumpitaz, 2008). While CSR initiatives provides information and character about the company (Brown \& Dacin, 1997), consumer trust is affected by the existence of values that the company and its consumer share (Morgan \& Hunt, 1994). These activities are useful for increasing the trust towards the organizations (Aaker, 2012). Thus, by injecting ethical and responsible principles into companies' strategic decision-making processes, firms can strengthen the trust of all stakeholders, including customers (Hosmer, 1994). Outside any contractual or legal constraints, the perceived CSR would stimulate trust-based relationships founded in the belief that all exchange partners' activities will be credible (Swaen \& Chumpitaz, 2008). Pivato et al. (2008, p. 5) supported this view by confirming that "the creation of trust is one of the most immediate consequences of a company's social performance". Based on the above arguments, this research proposes the following hypothesis:

\section{H2: Firms that are viewed more favorably with respect to CSR enjoy greater customer trust}

\section{CSR and Customer Loyalty:}

CSR may also influence loyalty (Sureshchandar et al., 2001, 2002; Maignan \& Ferrell, 2001). CSR can strengthen commitment towards a product or a service since it transmits respect for the customer and towards the society. This explains why consumers reward these efforts with loyalty towards the firm (Maignan et al., 1999). Furthermore, some authors have observed that a large number of consumers claimed to be more willing to buy products from companies involved in social causes (Ross et al., 1991, 1992; Jones, 1997). A number of studies demonstrated a positive direct relationship with no mediating variables between CSR and customer loyalty (García de los Salmones et al., 2005; He \& Li, 2011; Marin et al., 2009; Perez et al., 2013). Therefore, this research proposes the following hypothesis:

\section{H3: Firms that are viewed more favorably with respect to CSR enjoy greater customer loyalty}

\section{Customer Satisfaction and Customer Loyalty}

Several studies have revealed that customer satisfaction is positively correlated with loyalty, and satisfaction has been verified to be a leading factor in predicting loyalty (Hallowell, 1996, Bendall-Lyon \& Powers, 2003; Ehigie, 2006; Lam \& Burton, 2006; Ball et al., 2006; Hamadi, 2010). In other words, customer loyalty is observed as a direct outcome of customer satisfaction (Heskett et al., 1997). So, satisfied customers are more 
likely to use the same service, to resist competing brands and spread positive word of mouth (Bansawl et al., 2004, Chinomona \& Sandada, 2013). While unsatisfied customers are less likely to purchase additional services, tend to switch to other providers and to spread negative word-of-mouth (Bendall-Lyon \& Powers, 2003).

Most of the studies confirmed that satisfied clients have more possibility to repurchase and communicate positively toward an organization (Blodgett \& Anderson, 2000; Maxham \& Netemeyer, 2002). Wong and Sohal (2003) stated also that satisfying more consumer expectations during a service creates a higher repurchase probability for a company. Nevertheless, other studies revealed that high customer satisfaction does not always indicate high loyalty (Oliver, 1999; Seiders et al., 2005; Jones \& Sasser, 1995; Reichheld, 1996). This research proposes the following hypothesis:

\section{H4: Customer satisfaction has a positive effect on customer loyalty.}

\section{Customer Satisfaction and Customer Trust}

There is no consensus among researchers about the direction of causal link between customer satisfaction and customer trust. Thus, previous studies show bi-directional relationships between satisfaction and trust. Garbarino and Johnson (1999) found that customer satisfaction has a positive effect on customer satisfaction in the organization. This result was supported by Dabholkar and Sheng (2012) and Ou and Sia (2003) who tested the influence of satisfaction on trust in the context of online business transactions. Ou and Sia (2003) recommend that in order to enhance trust of internet customers, e-retailers need to firstly satisfy internet buyers on privacy and security issues. Olaru et al. (2008) emphasize that the positive experiences that customers have with sellers lead to satisfaction and the satisfying experiences consequently result in customer trust. Boshoff and Du Plessis (2009) argue that trust is crucial in relationships which means that customers need to have prior pleasing experiences leading to satisfaction then eventually leading to trust. These studies argue that customers firstly deal with the business and evaluate the business based on those experiences. If the experiences meet their expectations, then they become satisfied and will therefore trust the business. According to Aydin and Ozer (2005), in order to gain trust, one party must believe that another party will perform actions that will result in positive outcomes for it and the customer should perceive quality as positive. Therefore, in building trust, the customer should not only perceive positive outcomes but also believe these positive outcomes will continue in the future. However, other researchers argue that trust precedes satisfaction (Lin \& Wang, 2006; Chang, 2014). In this case, customers trust the service providers probably based on their image rather than on the past experience. This research hypothesizes that:

\section{H5: Customer satisfaction has a positive effect on customer trust.}

\section{Customer Trust and Customer Loyalty}

Many previous studies identified trust as a predictor of customer loyalty (Chaudhuri \& Holbrook, 2001; Liang \& Wong, 2004; Bibb \& Kourdi, 2007; Hsu, 2008; Deng et al., 2011; Gul, 2014; Kishada \& Wahab, 2015). In other words, when the customer is loyal towards a product or service, he is basically trusting in it (Gul, 2014). In the context of services marketing, Reichheld and Schefter (2000) confirmed that in order to gain the loyalty of the customers, you must first gain their trust. Thus, a customer loyalty to a company is enhanced by the trust created between the customer and the service provider (Kassim \& Abdullah, 2008; Kishada \& Wahab, 2015). The study of Bansal et al. (2004) showed that there is a significant positive relationship between customer trust and loyalty. The results are compatible with those of studies by Lin and Wang (2006). In the study conducted by So et al. (2013) trust is the strong determinant of customer loyalty. Avramakis (2011) studied the customer relationships in the Swiss Financial system and reported that customer trust positively predicts customer loyalty. Aydin and Ozer (2005) showed that perceived service qual- 
ity positively affected trust and trust has positive effect on loyalty. Deng et al. (2010) argued that achieving a customer trust is the main contributor to customer loyalty. Doney and Cannon (1997) showed also that trust has positive and significant effects on loyalty. In line with this prediction, Hsu (2007) argued that trust helps to attract new customers and later can retain existing ones besides influencing overall satisfaction. According to Hong and Cho (2011) the trustworthiness of a business plays a critical role in creating and maintaining customer loyalty. Further, Ranaweera and Prabhu (2003) highlighted that trust is a stronger emotion than satisfaction in predicting loyalty. These results confirm Hart and Johnson (1999) who argued also that trust may have more influence on customer loyalty than customer satisfaction.

Sirdeshmurk et al. (2002) developed a framework for understanding customer trust and loyalty relationship in two different service contexts (nonbusiness airline travels and cloth retail clothing industry). The results of this study revealed that the conversion of trust to loyalty involves complex, multiple-loop processes that require an understanding of (1) how specific trustworthiness dimensions can build greater consumer trust (2) how increased consumer trust can enhance value for the consumers; and (3) how value translates into loyalty. These results counter traditional beliefs that consumer trust converts directly into loyalty and indicate that such beliefs are overly simplistic and probably misleading. They suggested that managers instead of investing "blindly" in trust- building activities, in hopes that trust in and of itself produces loyalty, should have a careful understanding of trust conversion mechanisms. Such understandings are thus sensitive to contextual and industry factors and are likely to involve asymmetric influences. This research follows the dominant literature concerning the link between trust and loyalty and hypothesizes that:

H6: Customer trust has a positive effect on customer loyalty.

\section{Data Collection Method}

The questionnaire included

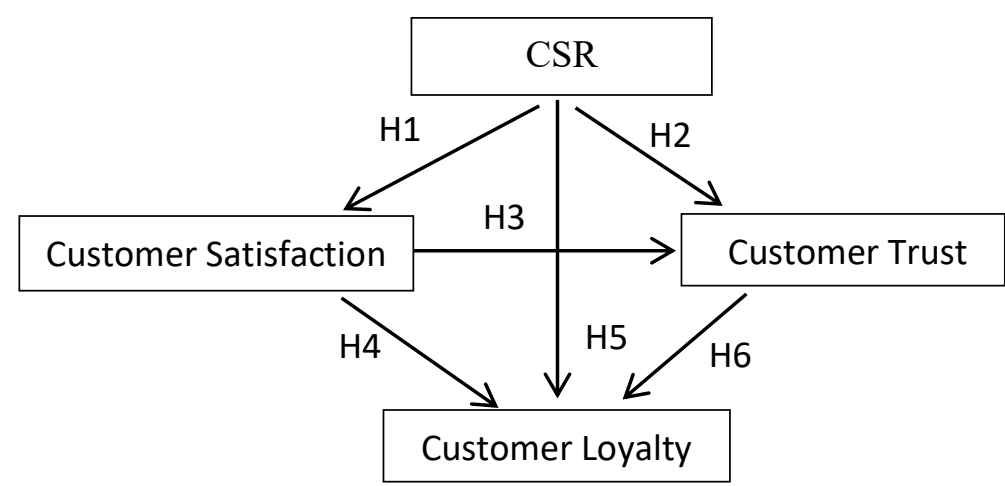

Figure 1: Conceptual framework

five main sections. The first section consisted of socio-demographic details (5 items): gender, marital status, age group, qualifications, and monthly income. Then, respondents were asked to estimate on a 5 point Likert scale their personal degree of agreement (where $1=$ "strongly disagree" and 5 = "strongly agree") with a number of statements regarding research four constructs: Corporate Social Responsibility (CSR): 2 items adapted from Martínez and Rodriguez del Bosque (2013), Customer Satisfaction (SAT): 5 items adapted from Cronin et al. (2000); Customer Trust (TRU): 3 items adapted from Fullerton (2011), and Customer Loyalty (LOY): 4 items adapted from Martínez and Rodriguez del Bosque (2013).

The questionnaire was created in google docs and published on different social media platforms (Facebook, Linkedln, WhatsApp). 410 Egyptian citizens ranging in age from 16 to above 65 year completed the questionnaire. Data were only collected from 329 people who use Uber service ${ }^{1}$. The sample had a fair representation of both genders (196 women and 133 men). To test the hypotheses generated we used the Partial Least Squares (PLS) approach using the Smart PLS Version 3. We used the PLS bootstrapping method to determine the significance levels for loadings, weights, and path coefficients.

1 Since its inception, Uber has expanded to reach more than 450 cities in 75 countries (Rizk, 2017). In Egypt, the taxi industry is highly regulated. New services, such as Uber and Careem, which use mobile internet technology to connect passengers and drivers, have begun to compete with traditional taxis. Uber started operating in Egypt in 2014 and has been expanding exponentially since then (Rizk, 2017). 


\section{Results}

\section{Socio-demographic analysis}

Table 1 deals with the socio-demographic characteristics of the respondents selected for the present study. First, it was observed that out of the total sample, $59.6 \%$ were female and $40.4 \%$ were male. Most of the users of Uber service were in the age group of $16-25(72.3 \%)$, then in the group of $26-35$ (15.5\%). As far as marital status is concerned, $82 \%$ of the people were single and $12.2 \%$ of them were married with children. Out of the total sample, $75 \%$ were highly educated with at least a bachelor's degree. Regarding monthly income, $46.2 \%$ were in the low-income group $(<2000)$, followed by the group of moderate income 2000 $<5000(24 \%)$

\section{Measurement of Variables}

The reliabilities of the measures were above the recommended value of .70 (Nunnally \& Bernstein, 1994) (CSR: 0.722; SAT: 0.890; TRU: 0.797; LOY: 0.819). The items for each construct and their scale of measurements are listed in Table 2.

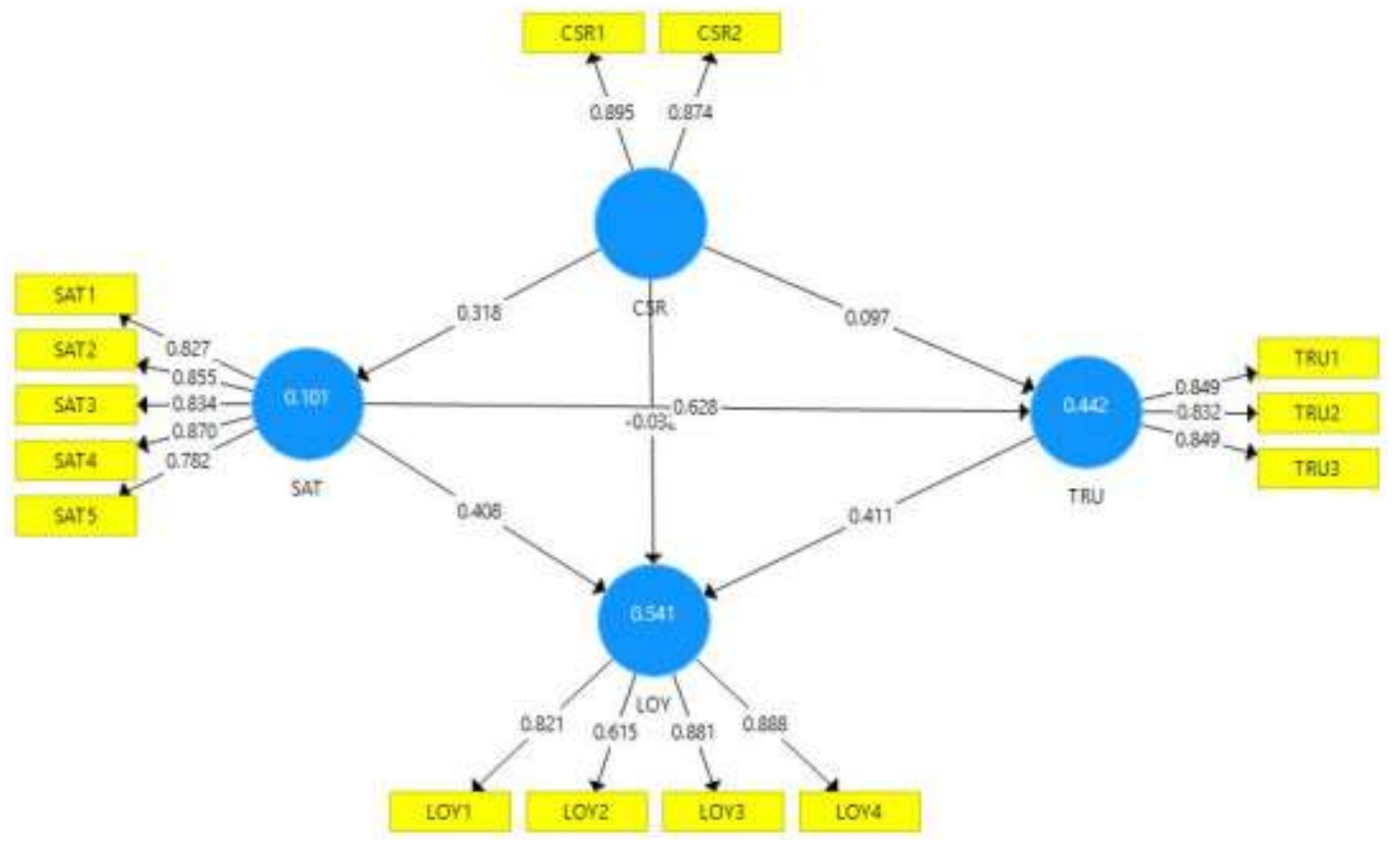

Figure 2: Measurement and Structural Model Results
Table 1: Sample socio-demographic profile

\begin{tabular}{|c|c|c|c|}
\hline & & Frequency & Percentage \\
\hline \multirow{2}{*}{ Gender } & Male & 133 & $40.4 \%$ \\
\hline & Female & 196 & $59.6 \%$ \\
\hline \multirow{4}{*}{$\begin{array}{l}\text { Marital } \\
\text { Status }\end{array}$} & Single & 270 & $82.0 \%$ \\
\hline & Married without children & 16 & $4.6 \%$ \\
\hline & Married with Children & 39 & $12.2 \%$ \\
\hline & Widow or divorced & 4 & $1.2 \%$ \\
\hline \multirow{6}{*}{ Age } & $16-25$ & 238 & $72.3 \%$ \\
\hline & $26-35$ & 51 & $15.5 \%$ \\
\hline & $36-45$ & 14 & $4.3 \%$ \\
\hline & $46-55$ & 19 & $5.8 \%$ \\
\hline & $56-65$ & 7 & $2.1 \%$ \\
\hline & More than 65 & 0 & $0.0 \%$ \\
\hline \multirow{4}{*}{ Education } & High School Diploma & 83 & $25.2 \%$ \\
\hline & Bachelor's degree & 172 & $52.3 \%$ \\
\hline & Master's degree & 56 & $17.0 \%$ \\
\hline & PhD degree & 18 & $5.5 \%$ \\
\hline \multirow{4}{*}{ Salary } & EP $2000>$ & 152 & $46.2 \%$ \\
\hline & EP $5000>-2000$ & 79 & $\% 24$ \\
\hline & EP 10000>- 5000 & 41 & $12.5 \%$ \\
\hline & EP 10000< & 57 & $17.3 \%$ \\
\hline
\end{tabular}




\section{Convergent Validity}

Convergent validity (internal consistency) was assessed using the average variance extracted (AVE) measure and Item loading values. According to Fornell and Lacker's (1981) the suggested benchmark should be 0.5 . As can be noted in Table 2, all the item loadings and AVE values reached the recommended benchmark - implying that all items converged well on the construct they were supposed to measure and so confirming the existence of convergent validity.

\section{Discriminant Validity}

To assess discriminant validity the AVE of the construct should be greater than the shared variance between the construct and the other model constructs (Chin, 1998). Table 3 lists the correlation matrix with correlation among constructs and the square root AVE on the diagonal. As shown in Table 3 , the diagonal elements are greater than the inter-construct correlations in the corresponding rows and columns, therefore confirming that discriminant validity indeed exist.

\section{Goodness of Fit Measurement}

To assess the global goodness-of-fit of our research model, Tenenhaus et al. $(2004,2005)$ proposed a method that takes into consideration both the quality of the measurement model and the structural model. Thus, the global goodness-of-fit (GoF) is calculated by applying the following equation:

\section{GoF=Sqrt $\left(\overline{\mathrm{AVE}} * \overline{\mathrm{R}^{2}}\right)$}

Where $\overline{A V E}$ represent the average of all AVE values for the research variables while $\overline{R^{2}}$ represents the average of all $R^{2}$ values in the full path model. The calculated GoF is 0.51 , which exceeds the recommended threshold of GoF $>0.36$ suggested by Wetzels et al. (2009). Thus, the research model provides an overall goodness of fit.

\section{Structural Equation Modeling Results}

The structural model was tested using the loadings and significance of the path coefficients (indicate the strengths of relationships between dependent and independent variables), and the $\mathrm{R}^{2}$ value (the amount of variance explained by independent variables).

The $\mathrm{R}^{2}$ values for the dependent variables: customer satisfaction (SAT), customer trust (TRU) and customer loyalty (LOY) are respectively $0.101,0.442$, and 0.541 . This result indicates that, on the overall model CSR explains only about $10 \%$ of customer satisfaction while customer satisfaction explains $44.2 \%$ of customer trust. Both customer satisfaction and customer trust explain about $54.1 \%$ of customer loyalty. 


\section{Hypotheses Test}

Consistent with the prediction of $\mathrm{H} 1$, the results in Table 4 indicate that there is a significant positive relationship between CSR and customer satisfaction $(\beta=0.318 ; \mathrm{t}=5.47)$. Therefore, $\mathrm{H} 1$ is supported. The standardized coefficient and the $t$ value do not give a support for the prediction of $\mathrm{H} 2(\beta=0.097 ; \mathrm{t}=1.453)$,

thus $\mathrm{H} 2$ is rejected. While $\mathrm{H} 3$ postulated a positive direct relationship between CSR and customer loyalty, the results indicate a negative association between the two constructs $(\beta=-0.032 ; \mathrm{t}=-1.597)$, thus $\mathrm{H} 3$ is not supported. $\mathrm{H} 4$ results indicate that customer satisfaction is positively associated with customer loyalty $(\beta=0.408 ; \mathrm{t}=3.334)$ and therefore $\mathrm{H} 4$ is supported. The results of $\mathrm{H} 5$ are also consistent with the prediction that the higher level of customer satisfaction, the higher level of customer trust $(\beta=0.628 ; t=13.776)$. Therefore, $\mathrm{H} 5$ is supported. Finally, the results in Table 4 are in line with $\mathrm{H} 6$ and support the prediction that the higher the level of customer trust, the higher the likelihood of their loyalty $(\beta=0.411 ; t=5.079)$. Thus, $\mathrm{H} 6$ is supported.

\section{Discussion of Findings}

In this research, it is proved that CSR initiatives by the company have positive and significant effect on customer satisfaction which is the key to customer trust and customer loyalty. The results confirm some of the previous studies about the influence of CSR on customer satisfaction (Daub \& Ergenzinger, 2005; Sen \& Bhattacharya, 2001; Luo \& Bhattacharya 2006; He \& Li, 2011). A strong perception of CSR by customers makes them care about not only the economic performance of the service or the product offered by the company but also about the overall role of the company in the society.

The results show that CSR has not a direct effect on customer loyalty. This result is different from the studies conducted by Murray and Vogel, (1997) who proved that CSR initiatives have a positive effect on customer attitude towards the product or service. Customer satisfaction was found to positively influence customer loyalty (H4). This result is in line with Lee (2010) whose study of predictors of customer loyalty in the Korean mobile phones confirmed the link between customer satisfaction and customer loyalty.

Our study also provided empirical evidence that satisfaction has a positive effect on trust (H5) and this trust will eventually has a positive influence on loyalty (H6). This supports the findings of Hallowell (1996), Bendall-Lyon and Powers (2003), Lam and Burton (2006), Ball et al. (2006) and Yap et al. (2012). Previous research found that trust also plays an important role in customer loyalty (Garbarino \& Johnson, 1999; Hart \& Johnson, 1999). Other studies stated that trust may have more influence on customer loyalty than customer satisfaction (Hart \& Johnson, 1999; Ranaweera \& Prabhu, 2003). The results of this research confirm this statement because the positive relationship between customer trust and customer loyalty is greater than the positive relationship between customer satisfaction and customer loyalty

Finally, we can conclude that CSR does not have a positive direct impact on loyalty, but its effect is fully mediated by customer satisfaction. In other words, differently from what was predicted in the model, the relationship between the CSR and customer loyalty cannot be expressed by a linear causal link. 


\section{Limitations and Recommendations}

Although this research, with 329 respondents, give good basis to understand the effect of CSR on customer satisfaction, trust, and loyalty, it would be more valuable and reliable to replicate this study with a larger number of respondents. Testing our research model in other industries and cultures could also enhance the generalization of our findings. Adding other constructs such as "perceived service quality" and "customer identification with the company", in further researches, could also enrich the literature on company-customer relationship

This study investigated the effect of CSR on customer satisfaction, trust, and loyalty. The results show that CSR does not influence customer loyalty directly as customer trust and customer satisfaction do. These results mean that companies most focus on communicating about sustainability elements like environment respect and their role to solve social problems to enhance trust with customers. Thus, social media can be a useful and effective tool for corporations in delivering sustainability messages as well as the reporting initiatives and results instead of using the traditional communication channels. This would help them to reach better for customers and communicate the value of their efforts and work and hence affect how customers perceive the corporation. Sharing the CSR reports will make sustainability efforts spread well and more widely (Johnston, 2014).

Companies need also to develop more sophisticated tools to measure and improve regularly customer satisfaction than traditional Customer Satisfaction Score (CSAT). Nowadays, social media has a significant influence on a business-customer relationship. It has offered a passage to reach out to millions of people and has become a perfect place to find out what people really feel about business. Facebook, Instagram, and Twitter are important platforms to track business and to measure efficiently customer satisfaction. 


\section{References}

- $\quad$ Aaker, D. A. (2012). Building strong brands. Simon and Schuster.

- $\quad$ Aaker, J. (1991). The negative attraction effect? A study of the attraction effect under judgment and choice. Advances in Consumer Research, 18, PP. 462-469.

- $\quad$ Agustin, C. \& Singh, J. (2005). “Curvilinear effects of consumer loyalty determinants in relational exchanges", Journal of Marketing Research, 42 (1), 96-108.

- Al-Msallam, S. (2015). "Customer satisfaction and brand loyalty in the hotel industry", International Journal of Management Sciences and Business Research, 4 (9), PP. 1-13.

- Al-Msallam, S. (2015). "The relationship between customer satisfaction and customer loyalty in the banking sector in Syria", Journal of Marketing and Consumer Research, 7, 27-34

- $\quad$ Anderson, E. W. \& Sullivan, M. W. (1993). "The antecedents and consequences of customer satisfaction for firms", Marketing Science, 12 (2), PP. 125-143.

- $\quad$ Anderson, E. W. (1996). “Customer satisfaction and price tolerance”, Marketing Letters, 7 (3), PP. 265-274.

- $\quad$ Anderson, E. W.; Fornell, C. \& Lehmann, D. R. (1994). “Customer satisfaction, market share, and profitability: Findings from Sweden", Journal of Marketing, 58 (3), PP. 53-66.

- $\quad$ Anderson, E. W.; Fornell, C. \& Rust, R. T. (1997). “Customer satisfaction, productivity, and profitability: differences between goods and services", Marketing Science, 16 (2), PP. 129-145.

- $\quad$ Aupperle, K. E.; Carroll, A. B. \& Hatfield, J. D. (1985). “An empirical examination of the relationship between corporate social responsibility and profitability", Academy of Management Journal, 28 (2), PP. 446-463.

- Avramakis, E. (2011). Relationship management in Swiss financial services: An investigation into relationship and bonding values of highly involved and confident customers. DBA thesis, Southern Cross University, Lismore, NSW.

- $\quad$ Aydin, S. \& Ozer, G. (2005). "The analysis of antecedents of customer loyalty in the Turkish mobile telecommunication market", European Journal of Marketing, 39 (7/8), PP. 910-925.

- Ball, D.; Coelho, P. S. \& Vilares, M. J. (2006). "Service personalization and loyalty", Journal of Services Marketing, 20 (6), PP. 391-403.

- Ball, D.; Simões Coelho, P. \& Machás, A. (2004). “The role of communication and trust in explaining customer loyalty: An extension to the ECSI model", European Journal of Marketing, 38 (9/10), PP. 1272-1293.

- $\quad$ Bansal, H. S.; Irving, P. G. \& Taylor, S. F. (2004). "A three-component model of customer to service providers", Journal of the Academy of Marketing Science, 32 (3), PP. 234-250.

- Barney, J. (1991). "Firm resources and sustained competitive advantage", Journal of Management, 17 (1), PP. 99-120.

- Barney, J. B. (2001). "Resource-based theories of competitive advantage: A ten-year retrospective on the resource-based view", Journal of Management, 27 (6), PP. 643-650.

- Bendall-Lyon, D. \& Powers, T. L. (2003). "The influence of mass communication and time on satisfaction and loyalty", Journal of Services Marketing, 17 (6), PP. 589-608.

- $\quad$ Berens, G.; Van Riel, C. B. \& Van Bruggen, G. H. (2005). “Corporate associations and consumer product responses: The moderating role of corporate brand dominance", Journal of Marketing, 69 (3), PP. 35-48. 
Bibb, S., \& Kourdi, J. (2007). A question of trust. London: Marshall Cavendish

Blodgett, J. G., \& Anderson, R. D. (2000). A Bayesian network model of the consumer complaint process. Journal of Service Research, 2(4), 321-338.

- Boshoff, C., \& Du Plessis, P. J. (2009). Services marketing: A contemporary approach. Juta and Company Ltd.

- $\quad$ Boulding, W., Kalra, A., Staelin, R., \& Zeithaml, V. A. (1993). A dynamic process model of service quality: from expectations to behavioral intentions. Journal of Marketing Research, 30(1), 7-27.

- Brown, T. J., \& Dacin, P. A. (1997). The company and the product: Corporate associations and consumer product responses. Journal of Marketing, 61(1), 68-84.

- $\quad$ Brown, T. J., Barry, T. E., Dacin, P. A., \& Gunst, R. F. (2005). Spreading the word: Investigating antecedents of consumers' positive word-of-mouth intentions and behaviors in a retailing context. Journal of the Academy of marketing science, 33(2), 123-138.

- $\quad$ Burton, S., Lichtenstein, D. R., Netemeyer, R. G., \& Garretson, J. A. (1998). A scale for measuring attitude toward private label products and an examination of its psychological and behavioral correlates. Journal of the Academy of Marketing Science, 26(4), 293-306.

- $\quad$ Cadotte, E. R., Woodruff, R. B., \& Jenkins, R. L. (1987). Expectations and norms in models of consumer satisfaction. Journal of Marketing Research, 24(3), 305-314.

- Calabrese, A., Costa, R., \& Rosati, F. (2016). Gender differences in customer expectations and perceptions of corporate social responsibility. Journal of Cleaner Production, 116(1), 135-149.

- $\quad$ Carpenter, G. S., \& Lehmann, D. R. (1985). A model of marketing mix, brand switching, and competition. Journal of Marketing Research, 22(3), 318-329.

- Carrillat, F. A., Jaramillo, F., \& Mulki, J. P. (2009). Examining the impact of service quality: a meta-analysis of empirical evidence. Journal of Marketing Theory and Practice, 17 (2), 95-110.

- $\quad$ Carroll, A. B. (1979). A three-dimensional conceptual model of corporate performance. Academy of Management Review, 4(4), 497-505.

- $\quad$ Cater, B., \& Zabkar, V. (2009). Antecedents and consequences of commitment in marketing research services: The client's perspective. Industrial Marketing Management, 38(7), 785-797.

- $\quad$ Chang, K. C. (2014). Examining the effect of tour guide performance, tourist trust, tourist satisfaction, and flow experience on tourists' shopping behavior. Asia Pacific Journal of Tourism Research, 19(2), 219-247.

- $\quad$ Chaudhuri, A., \& Holbrook, M. B. (2001). The chain of effects from brand trust and brand affect to brand performance: the role of brand loyalty. Journal of Marketing, 65(2), 81-93.

- Chin, W. W. (1998). Commentary: Issues and opinion on structural equation modeling. MIS Quarterly, 22(1), vii-xvi.

- Chinomona, R., \& Sandada, M. (2013). Customer satisfaction, trust, and loyalty as predictors of customer intention to re-purchase South African retailing industry. Mediterranean Journal of Social Sciences, 4(14), 437-446.

- Colombo, R. A., \& Morrison, D. G. (1989). Note-A brand switching model with implications for marketing strategies. Marketing Science, 8(1), 89-99.

- Crespo, A. H., \& Rodriguez del Bosque, I. (2005). Influence of corporate social responsibility on loyalty and valuation of services. Journal of Business Ethics, 61(4), 369-385.

Cronin Jr, J. J., \& Taylor, S. A. (1992). Measuring service quality: a reexamination and extension. JournalofMarketing, 56(3), 55-68. 
Cronin Jr, J. J., Brady, M. K., \& Hult, G. T. M. (2000). Assessing the effects of quality, value, and customer satisfaction on consumer behavioral intentions in service environments. Journal of Retailing, 76(2), 193-218.

- Crosby, L., Evans, K.R., Cowles, D. (1990). Relationship quality in services selling: an interpersonal influence perspective. Journal of Marketing, 54(3), 68-81.

- Dabholkar, P. A., \& Sheng, X. (2012). Consumer participation in using online recommendation agents: Effects on satisfaction, trust, and purchase intentions. The Service Industries Journal, 32(9), 1433-1449.

- Daub, C. H., \& Ergenzinger, R. (2005). Enabling sustainable management through a new multi-disciplinary concept of customer satisfaction. European Journal of Marketing, 39(9/10), 998-1012.

- Dekimpe, M. G., Steenkamp, J. B. E., Mellens, M., \& Abeele, P. V. (1997). Decline and variability in brand loyalty. International Journal of Research in Marketing, 14(5), 405-420.

- Deng, Z., Lu, Y., Wei, K. K., \& Zhang, J. (2010). Understanding customer satisfaction and loyalty: An empirical study of mobile instant messages in China. International Journal of Information Management, 30(4), 289-300.

- $\quad$ Dick, A. S., \& Basu, K. (1994). Customer loyalty: toward an integrated conceptual framework. Journal of the Academy of Marketing Science, 22(2), 99-113.

- Dijkstra, T. K., \& Henseler, J. (2015). Consistent and asymptotically normal PLS estimators for linear structural equations. ComputationalStatistics \& Data Analysis, 81(1):10-23

- Doney, P.M. and Cannon, J.P. (1997). An examination of the nature of the trust in buyer-seller relationship, Journal of Marketing, 61(2), 35-51.

- Du, S., Bhattacharya, C. B., \& Sen, S. (2007). Reaping relational rewards from corporate social responsibility: The role of competitive positioning. International Journal of Research in Marketing, 24(3), 224-241.

- $\quad$ Ehigie, B. O. (2006). Correlates of customer loyalty to their bank: A case study in Nigeria. International Journal of Bank Marketing, 24(7), 494-508.

- $\quad$ Eller, P. S., Lois, A. M., \& Webb, D. J. (2000). Charitable programs and the retailer: Do they mix? Journal of Retailing, 76(3), 393-406.

- Fornell, C. (1992). A national customer satisfaction barometer: The Swedish experience. the Journal of Marketing, 56(1), 6-21.

- $\quad$ Fornell, C., \& Larcker, D.F. (1981). Evaluating structural equation models with unobservable variables and measurement error. Journal of Marketing Research, 18(1), 39- 50.

- Frederick, F. R., \& Thomas, T. E. A. L. (1996). The loyalty effect: The hidden force behind growth, profits, and lasting value. Harvard Business School Press, Boston, Massachusetts.

- Fullerton, G. (2011). Creating advocates: The roles of satisfaction, trust, and commitment. Journal of Retailing and Consumer Services, 18(1), 92-100.

- Ganesan, S. (1994). Determinants of long-term orientation in buyer-seller relationships. Journal of marketing, 58(2), 1-19.

- Garbarino, E., \& Johnson, M. S. (1999). The different roles of satisfaction, trust, and commitment in customer relationships. Journal of Marketing, 63(2), 70-87.

- García de los Salmones, M. M., Herrero, A., \& Rodríguez del Bosque, I. (2005). Influence of corporate social responsibility on loyalty and valuation of services. Journal of Business Ethics, 61(4), 369-385. 
Gul, R. (2014). “The relationship between reputation, customer satisfaction, trust, and loyalty", Journal of Public Administration and Governance, 4 (3), PP. 368-387.

Hagoveldand, N. M. \& Svensson, G. (2011). "A business sustainability model", Journal of Business \& Industrial Marketing, 27 (2), 142-151.

- Hallowell, R. (1996). "The relationships of customer satisfaction, customer loyalty, and profitability: an empirical study", InternationalJournal of Service Industry Management, 7 (4), PP. 27-42.

- Hamadi, C. (2010). "The impact of quality of online banking on customer commitment", Communications of the IBIMA, PP. 1-8.

- Han, H. \& Back, K. J. (2008). “Relationships among image congruence, consumption emotions, and customer loyalty in the lodging industry", Journal of Hospitality \& Tourism Research, 32 (4), PP. 467-490.

- Han, H.; Kim, Y. \& Kim, E. K. (2011). “Cognitive, affective, conative, and action loyalty: Testing the impact of inertia", International Journal of Hospitality Management, 30 (4), PP. 1008-1019.

Harris, E. G.; Mowen, J. C. \& Brown, T. J. (2005). “Re-examining salesperson goal orientations: personality influencers, customer orientation, and work satisfaction", Journal of the Academy of Marketing Science, 33 (1), PP. 19-35.

- Harris, L. C. \& Goode, M. M. (2004). “The four levels of loyalty and the pivotal role of trust: A study of online service dynamics", Journal of Retailing, 80 (2), PP. 139-158.

- Hart, C. W. \& Johnson, M. D. (1999). “Growing the trust relationship", Marketing Management, 8 (1), 9-19.

- He, H. \& Li, Y. (2011). "CSR and service brand: The mediating effect of brand identification and moderating effect of service quality", Journal of Business Ethics, 100 (4), PP. 673-688.

Heskett, J. L.; Sasser, W. E. \& Schlesinger, L. A. (1997). The service profit chain. Simon and Schuster.

- Hong, I. B. \& Cho, H. (2011). “The impact of consumer trust on attitudinal loyalty and purchase intentions in B2C e-marketplaces: Intermediary trust vs. seller trust", International Journal of Information Management, 31 (5), PP. 469-479.

- Hosmer, L. T. (1994). "Strategic planning as if ethics mattered", Strategic Management Journal, 15 (S2), 17-34.

Howard, J. A. (1994). Buyer behavior in marketing strategy. Prentice Hall.

Hsu, C. J. (2008, September). “Dominant factors for online trust", In: 2008 International Conference on Cyberworlds, PP. 165-172.

Hsu, S. H. (2007). Developing an index for online customer satisfaction: adaptation of American Customer Satisfaction Index. Expert Systems with Applications, 34 (4), PP. 3033-3042.

- Islam, T.; Attiq, S.; Hameed, Z.; Khokhar, M. N. \& Sheikh Z. (2018). "The impact of self-congruity (symbolic and functional) on the brand hate: A study based on self-congruity theory", British Food Journal, 121 (1), PP. 71-88.

- Islam, T.; Islam, R.; Pitafi, A. H.; Xiaobei, L.; Rehmani, M.; Irfan, M. \& Mubarak, M. S. (2021). «The impact of corporate social responsibility on customer loyalty: The mediating role of corporate reputation, customer satisfaction, and trust", Sustainable Production and Consumption, 25, PP. 123-135.

- Islam, T.; Li, J.; Ali. A.; Xiaobei, L.; Sheikh, Z. \& Zafar, A. U. (2020). “Mapping online App hate: Determinants and consequences", Telematics and Informatics, 51, PP. 101-104. 
Jacoby, J. \& Kyner, D. B. (1973). “Brand loyalty vs. repeat purchasing behavior", Journal of Marketing Research, 10 (1), 1-9.

- Jamal, A., \& Goode, M. (2001). “Consumers' product evaluation: A study of the primary evaluative criteria in the precious jewellery market in the UK", Journal of Consumer Behaviour, 1 (2), PP. 140-155.

- Jeuland, A. P. (1979). "Brand choice inertia as one aspect of the notion of brand loyalty", Management Science, 25 (7), PP. 671-682.

- $\quad$ Jin, Y. J.; Park, S. C. \& Yoo, J. W. (2017). “Effects of corporate social responsibility on consumer credibility perception and attitude toward luxury brands", Social Behavior and Personality, 45 (5), PP. 795-808.

- Johnson, M. D. \& Fornell, C. (1991). "A framework for comparing customer satisfaction across individuals and product categories", Journal of Economic Psychology, 12 (2), PP. 267-286.

- Johnson, M. D.; Herrmann, A. \& Huber, F. (2006). "The evolution of loyalty intentions", Journal of Marketing, 70 (2), PP. 122-132.

- Johnston L. A. (2014). "Connecting sustainability reporting and social media", The National Provisioner, https://www.provisioneronline.com/articles/99985-connecting-sustainability-reporting-and-social-media.

- Jones, D. (1997). “Good works, good business", U.S.A. Today (April 25), 1B-2B.

- Jones, T. O. \& Sasser, W. E. (1995). «Why satisfied customers defect", Harvard Business Review, 73 (6), PP. 88-99.

- Kassim, N. \& Asiah Abdullah, N. (2010). “The effect of perceived service quality dimensions on customer satisfaction, trust, and loyalty in e-commerce settings: A cross cultural analysis", Asia Pacific Journal of Marketing and Logistics, 22 (3), PP. 351-371.

- $\quad$ Kennedy, M. S.; Ferrell, L. K. \& LeClair, D. T. (2001). “Consumers' trust of salesperson and manufacturer: An empirical study", Journal of Business Research, 51 (1), PP. 73-86.

- Kishada, Z. M. E. \& Wahab, N. A. (2015). "Influence of customer satisfaction, service quality, and trust on customer loyalty in Malaysian Islamic banking", International Journal of Business and Social Science, 6 (11), PP. 110-119.

- Klein, J.\& Dawar, N. (2004). “Corporate social responsibility and consumers' attributions and brand evaluations in a product-harm crisis", International Journal of Research in Marketing, 21 (3), PP. 203-217.

- Kotler, P. (1994). Marketing management: analysis, planning, implementation, and control. The Prentice-Hall in Marketing.

- $\quad$ Lam, R. \& Burton, S. (2006). "SME banking loyalty (and disloyalty): A qualitative study in Hong Kong", International Journal of Bank Marketing, 24 (1), PP. 37-52.

- Lee, H. S. (2010). "Factors influencing customer loyalty of mobile service: Empirical evidence from Koreans", Journal of International Banking and Commerce, 15 (2), PP. 1-14.

- $\quad$ Lee, J.; Lee, J. \& Feick, L. (2001). “The impact of switching costs on the customer satisfaction-loyalty link: mobile phone service in France", Journal of Services Marketing, 15 (1), PP. 35-48.

- $\quad$ Lee, K. Y.; Huang, H. L. \& Hsu, Y. C. (2007). “Trust, satisfaction, and commitment-on loyalty to international retail service brands", Asia Pacific Management Review, 12 (3), PP. 161-169. 
Leninkumar, V. (2017). “The relationship between customer satisfaction and customer trust on customer loyalty", International Journal of Academic Research in Business and Social Sciences, 7 (4), PP. 450-465.

- $\quad$ Liang, C. J. \& Wang, W. H. (2005). “Integrative research into the financial services industry in Taiwan: Relationship bonding tactics, relationship quality and behavioural loyalty", Journal of Financial Services Marketing, 10 (1), PP. 65-83.

- $\quad$ Lin, H. H. \& Wang, Y. S. (2006). "An examination of the determinants of customer loyalty in mobile commerce contexts", Information and Management, 43 (3), PP. 271-282.

- $\quad$ Lo, A. S.; Stalcup, L. D. \& Lee, A. (2010). “Customer relationship management for hotels in Hong Kong", International Journal of Contemporary Hospitality Management, 22 (2), PP. 139-159. Luo, X. \& Bhattacharya, C. B. (2006). “Corporate social responsibility, customer satisfaction, and market value", Journal of Marketing, 70 (4), PP. 1-18.

- Maignan, I. \& Ferrell, O. C. (2000). “Measuring corporate citizenship in two countries: The case of the United States and France", Journal of Business Ethics, 23, PP. 283-297.

- Maignan, I. \& Ferrell, O. C. (2001). “Antecedents and benefits of corporate citizenship: An investigation of French businesses", Journal of Business Research, 51 (1), PP. 37-51.

- Maignan, I.; Ferrell, O. C. \& Ferrell, L. (2005). “A stakeholder model for implementing social responsibility in marketing", European Journal of Marketing, 39 (9/10), PP. 956-977.

- Maignan, I.; Ferrell, O. C. \& Hult, G. T. M. (1999). “Corporate citizenship: Cultural antecedents and business benefits", Journal of the Academy of Marketing Science, 27 (4), PP. 455-469.

- Marin, L.; Ruiz, S. \& Rubio, A. (2009). "The role of identity salience in the effects of corporate social responsibility on consumer behavior", Journal of Business Ethics, 84 (1), PP. 65-78.

Martinez, P. \& Rodriguez del Bosque, I. (2013). “CSR and customer loyalty: The roles of trust, customer identification with the company and satisfaction", International Journal of Hospitality Management, 35, PP. 89-99.

- Martinez, P.; Pérez, A. \& Rodriguez del Bosque, I. (2013). “Measuring corporate social responsibility in tourism: Development and validation of an efficient measurement scale in the hospitality industry", Journal of Travel \& Tourism Marketing, 30 (4), PP. 365-385.

- Maxham III, J. G. \& Netemeyer, R. G. (2002). “A longitudinal study of complaining customers' evaluations of multiple service failures and recovery efforts", Journal of Marketing, 66 (4), PP. 57-71.

- McCole, P. (2002). "The role of trust for electronic commerce in services", InternationalJournal of Contemporary HospitalityManagement, 14 (2), PP. 81-87.

- McQuitty, S.; Finn, A. \& Wiley, J. B. (2000). "Systematically varying consumer satisfaction and its implications for product choice", Academy of Marketing Science Review, 10 (1), PP. 231-254.

- $\quad$ McWilliams, A. \& Siegel, D. S. (2011). “Creating and capturing value: Strategic corporate social responsibility, resource-based theory, and sustainable competitive advantage", Journal of Management, 37 (5), PP. 1480-1495.

Morgan, R. M. \& Hunt, S. D. (1994). “The commitment-trust theory of relationship marketing”, Journal of Marketing, 58 (3), PP. 20-38.

- $\quad$ Murray, K. B. \& Vogel, C. M. (1997). “Using a hierarchy-of-effects approach to gauge the effectiveness of corporate social responsibility to generate goodwill toward the firm: Financial versus nonfinancial impacts", Journal of Business Research, 38 (2), 141-159. 
Narayandas, N. (1996). The link between customer satisfaction and customer loyalty: an empirical investigation. Division of Research, Harvard Business School.

- Nunnally, J. \& Bernstein, I. (1994). Psychometric Theory. ( $3^{\text {rd }}$ Ed). MacGraw-Hill, New York.

- Nyadzayo, M. W. \& Khajehzadeh, S. (2016). “The antecedents of customer loyalty: A moderated mediation model of customer relationship management quality and brand image", Journal of Retailing and Consumer Services, 30, 262-270.

- $\quad$ Olaru, D.; Purchase, S. \& Peterson, N. (2008). “From customer value to repurchase intentions and recommendations", Journal of Business and Industrial Marketing, 23 (8), PP. 558-565.

- Oliver, R. L. (1981). "Measurement and evaluation of satisfaction processes in retail settings", Journal of Retailing. 57 (3), PP. 25-48.

- Oliver, R. L. (1993). “Cognitive, affective, and attribute bases of the satisfaction response”, Journal of Consumer Research, 20 (3), 418-430.

- Oliver, R. L. (1997). Satisfaction: A behavioral perspective on the consumer. MacGraw-Hill, New York.

- Oliver, R. L. (1999). “Whence consumer loyalty?”, Journal of Marketing,63 (4_suppl1), PP. 33-44.

- $\quad$ Ou, C. X. \& Sia, C. L. (2003, July). Customer loyalty strategy in the internet era. $7^{\text {th }}$ ed. Pacific Asia Conference on Information Systems, Adelaide, South Australia.

- Panwar, R.; Rinne, T.; Hansen, E. \& Juslin, H. (2006). “Corporate responsibility”, Forest Products Journal, 56 (2), 4-12.

- Pivato, S.; Misani, N. \& Tencati, A. (2008). "The impact of corporate social responsibility on consumer trust: the case of organic food", Business Ethics: A European Review, 17 (1), 3-12.

- Price, L. L. \& Arnould, E. J. (1999). “Commercial friendships: Service provider-client relationships in context", Journal of Marketing, 63(4), PP. 38-56.

- Pérez, A. \& Rodriguez del Bosque, I. (2013). «Measuring CSR image: three studies to develop and to validate a reliable measurement tool", Journal of Business Ethics, 118 (2), PP. 265-286.

- Pérez, A.; del Mar García de los Salmones, M. \& Rodríguez del Bosque, I. (2013). "The effect of corporate associations on consumer behaviour. European Journal of Marketing, 47 (1/2), PP. 218-238.

- $\quad$ Ranaweera, C. \& Prabhu, J. (2003). “On the relative importance of customer satisfaction and trust as determinants of customer retention and positive word of mouth", Journal of Targeting, Measurement and Analysis for Marketing, 12 (1), PP. 82-90.

- $\quad$ Reichheld, F. F. (1996). The quest for loyalty: creating value through partnership. Harvard Business Press.

- $\quad$ Rizk, N. (2017). A glimpse into the sharing economy: An analysis of Uber driver-partners in Egypt. http://dx.doi.org/10.2139/ssrn.2946083

- $\quad$ Ross III, J. K.; Patterson, L. T. \& Stutts, M. A. (1992). “Consumer perceptions of organizations that use cause-related marketing", Journal of the Academy of Marketing science, 20 (1), PP. 93-97.

- $\quad$ Ross III, J. K.; Stutts, M. A. \& Patterson, L. (1991). “Tactical considerations for the effective use of cause-related marketing", Journal of Applied Business Research, 7, (2), PP. 58-65.

- $\quad$ Roy, S. K. (2013). “Consequences of customer advocacy”, Journal of Strategic Marketing, 21 (3), PP. 260-276. 
Russell, G. J. \& Kamakura, W. A. (1994). “Understanding brand competition using micro and macro scanner data", Journal of Marketing Research, 31 (2), PP. 289-303.

- $\quad$ Seiders, K.; Voss, G. B.; Grewal, D. \& Godfrey, A. L. (2005). “Do satisfied customers buy more? Examining moderating influences in a retailing context", Journal of Marketing, 69 (4), PP. 26-43.

- $\quad$ Sen, S. \& Bhattacharya, C. B. (2001). “Does doing good always lead to doing better? Consumer reactions to corporate social responsibility",Journal of Marketing Research,38 (2), PP. 225-243.

- Simon, D. H.; Gómez, M. I.; McLaughlin, E. W. \& Wittink, D. R. (2009). “Employee attitudes, customer satisfaction, and sales performance: Assessing the linkages in US grocery stores", Managerial and Decision Economics, 30 (1), PP. 27-41.

- Sindhu, M. I. \& Arif, M. (2017). “Corporate social responsibility and loyalty: Intervening influence of customer satisfaction and trust", Cogent Business \& Management, 4 (1), PP. 1-10.

- $\quad$ Sirdeshmukh, D.; Singh, J. \& Sabol, B. (2002). “Consumer trust, value, and loyalty in relational exchanges", Journal of Marketing, 66 (1), PP. 15-37.

- Sivakumar, K. (1995). "The role of quality-tier loyalty on consumer price sensitivity for frequently purchased products", Journal of Marketing Theory and Practice, 3 (4), PP. 84-96.

- $\quad$ Smith, S. M. \&Alcorn, D. S. (1991). “Cause marketing: A new direction in the marketing of corporate responsibility", Journal of Consumer Marketing, 8 (3), PP. 19-35.

- So, K. K. F.; King, C.; Sparks, B. \& Wang, Y. (2013). "The influence of customer brand identification on hotel brand evaluation and loyalty development", International Journal of Hospitality Management, 34, PP. 31-41.

- $\quad$ Stroup, M. A. \& Neubert, R. L. (1987). “The evolution of social responsibility”, Business Horizons, 30, PP. 22-24.

- $\quad$ Sureshchandar, G. S.; Rajendran, C. \& Anantharaman, R. N. (2002). “The relationship between service quality and customer satisfaction: A factor specific approach", Journal of Services Marketing, 16 (4), PP. 363-379.

- Swaen, V. \& Chumpitaz, R. C. (2008). "Impact of corporate social responsibility on consumer trust", Recherche et Applications en Marketing (English Edition), 23, (4), PP. 7-34.

- Takala, J.; Bhufhai, A. \& Phusavat, K. (2006). «Proposed verification method for the content suitae bility of the customer satisfaction survey", Industrial Management \& Data Systems, 106 (6), PP. 841-854.

- Tellis, G. J. (1988). "Advertising exposure, loyalty, and brand purchase: A two-stage model of choice", Journal of Marketing Research, 25 (2), PP. 134-144.

- $\quad$ Tenenhaus, M.; Amato, S. \& Esposito Vinzi, V. (2004, June). “A global goodness-of-fit index for PLS structural equation modelling", In: Proceedings of the XLII SIS Scientific Meeting, 1, PP. 739-742.

- Tenenhaus, M.; Esposito Vinzi, V.; Chatelin, Y. M. \& Lauro, C. (2005). “PLS path modeling”, Computational Statistics \& DataAnalysis, 48 (1), PP. 159-205.

- Van Marrewijk, M. (2003). “Concepts and definitions of CSR and corporate sustainability: Between agency and communion", Journal of Business Ethics, 44 (2-3), PP. 95-105.

- Varadarajan, P. R. \& Menon, A. (1988). “Cause-related marketing: A coalignment of marketing strategy and corporate philanthropy", Journal of Marketing, 52 (3), PP. 58-74.

Wah Yap, B.; Ramayah, T. \& Nushazelin Wan Shahidan, W. (2012). "Satisfaction and trust on customer loyalty: A PLS approach", Business Strategy Series, 13 (4), PP. 154-167. 
- Wallin Andreassen, T. (2000). "Antecedents to satisfaction with service recovery", European Journal of Marketing, 34 (1/2), PP. 156-175.

- Wetzels, M.; Odekerken-Schröder, G. \& Van Oppen, C. (2009). “Using PLS path modeling for assessing hierarchical construct models: Guidelines and empirical illustration", MIS Quarterly, 33 (1),PP. 177-195.

- White, P. (2009). "Building a sustainability strategy into the business", Corporate Governance: The International Journal of Business in Society, 9 (4), PP. 386-394.

- Wong, A. \& Sohal, A. (2003). "A critical incident approach to the examination of customer relationship management in a retail chain: An exploratory study", Qualitative Market Research, 6 (4), PP. 248-262.

- $\quad$ Woodruff, R. B.; Cadotte, E. R. \& Jenkins, R. L. (1983). “Modeling consumer satisfaction processes using experience-based norms", Journal of Marketing Research, 20 (3), PP. 296-304.

- Wu, S. I. \& Wang, W. H. (2014). "Impact of CSR perception on brand image, brand attitude and buying willingness: A study of a global café", International Journal of Marketing Studies, 6 (6), PP. 43-56. 